\title{
M. Célia Martirani, Il Dilemma del mandarino
}

\section{Marco Stupazzoni}

\section{OpenEdition}

\section{Journals}

\section{Edizione digitale}

URL: http://journals.openedition.org/studifrancesi/10673

DOI: 10.4000/studifrancesi. 10673

ISSN: 2421-5856

\section{Editore}

Rosenberg \& Sellier

\section{Edizione cartacea}

Data di pubblicazione: 1 décembre 2017

Paginazione: 566

ISSN: 0039-2944

\section{Notizia bibliografica digitale}

Marco Stupazzoni, «M. Célia Martirani, /l Dilemma del mandarino», Studi Francesi [Online], 183 (LXI | III) | 2017, online dal 01 février 2018, consultato il 24 janvier 2021. URL: http://journals.openedition.org/ studifrancesi/10673 ; DOI: https://doi.org/10.4000/studifrancesi.10673

Questo documento è stato generato automaticamente il 24 janvier 2021.

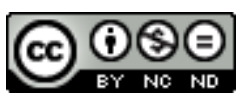

Studi Francesi è distribuita con Licenza Creative Commons Attribuzione - Non commerciale - Non opere derivate 4.0 Internazionale. 


\title{
M. Célia Martirani, Il Dilemma del mandarino
}

\author{
Marco Stupazzoni
}

\section{NOTIZIA}

MARIA CÉLIA MARTIRANI, Il Dilemma del mandarino, in Lucida follia. Saggi di letteratura dal boom ispanico ad Alessandro Baricco, premessa di Claudio Magris, Firenze, Franco Cesati Editore, 2016, «Strumenti di Letteratura Italiana», pp. 51-62.

1 Prendendo spunto da una recente edizione brasiliana de La Comédie humaine curata con grande devozione dal critico ungherese Paulo Rónai, l'A. ripercorre, in questo saggio, alcune tra le tematiche più rilevanti che attraversano l'universo romanzesco dello scrittore francese. Specchio di un'epoca sotto il profilo della storia dei costumi, dell'evoluzione della vita privata e collettiva, dei poteri, delle idee e delle passioni, $L a$ Comédie humaine - nella quale i romanzi e i racconti che la compongono «non cominciano mai, né finiscono» (p. 53) - illustra la genialità di un romanziere che, molto prima di Freud, ha saputo «osservare l'essere umano in tutte le sue manifestazioni» (p.61) e in molte di quelle contraddizioni e di quegli antagonismi ideologici tra individuo e realtà che caratterizzeranno i protagonisti dei romanzi contemporanei. Nel Père Goriot, il giovane Rastignac, appena giunto dalla provincia a Parigi, la «cittàfiamma», non cederà alle proposte criminali di Vautrin, ma risolverà autonomamente il suo «dilemma del mandarino», la sua crisi di coscienza trasformandosi, da idealista ingenuo, ad arrivista senza scrupoli. 